\title{
Bisphenol A increases hydrogen peroxide generation by thyrocytes both in vivo and in vitro
}

\author{
Maurício Martins da Silva ${ }^{1}$, Lueni Lopes Felix Xavier ${ }^{1}$, Carlos Frederico Lima Gonçalves $^{1}$, \\ Ana Paula Santos-Silva ${ }^{1,2}$, Francisca Diana Paiva-Melo', Mariana Lopes de Freitas', Rodrigo Soares Fortunato ${ }^{3}$, \\ Leandro Miranda-Alves ${ }^{1}$ and Andrea Claudia Freitas Ferreira ${ }^{1,2}$
}

${ }^{1}$ Laboratory of Endocrine Physiology, Instituto de Biofísica Carlos Chagas Filho, Universidade Federal do Rio de Janeiro, Rio de Janeiro, Brasil ${ }^{2}$ NUMPEX, Campus Duque de Caxias, Universidade Federal do Rio de Janeiro, Rio de Janeiro, Brasil

${ }^{3}$ Laboratory of Molecular Radiobiology, Instituto de Biofísica Carlos Chagas Filho, Universidade Federal do Rio de Janeiro, Rio de Janeiro, Brasil

Correspondence should be addressed to A C F Ferreira: andclauf@yahoo.com.br

\begin{abstract}
Bisphenol A (BPA) is the most common monomer in polycarbonate plastics and an endocrine disruptor. Though some effects of BPA on thyroid hormone (TH) synthesis and action have been described, the impact of this compound on thyroid $\mathrm{H}_{2} \mathrm{O}_{2}$ generation remains elusive. $\mathrm{H}_{2} \mathrm{O}_{2}$ is a reactive oxygen species (ROS), which could have deleterious effect on thyrocytes if in excess. Therefore, herein we aimed at evaluating the effect of BPA exposition both in vivo and in vitro on $\mathrm{H}_{2} \mathrm{O}_{2}$ generation in thyrocytes, besides other essential steps for TH synthesis. Female Wistar rats were treated with vehicle (control) or BPA $40 \mathrm{mg} / \mathrm{kg}$ BW for 15 days, by gavage. We then evaluated thyroid iodide uptake, mediated by sodium-iodide symporter (NIS), thyroperoxidase (TPO) and dual oxidase (DOUX) activities $\left(\mathrm{H}_{2} \mathrm{O}_{2}\right.$ generation). Hydrogen peroxide generation was increased, while iodide uptake and TPO activity were reduced by BPA exposition. We have also incubated the rat thyroid cell line PCCL3 with $10^{-9} \mathrm{M}$ BPA and evaluated Nis and Duox mRNA levels, besides $\mathrm{H}_{2} \mathrm{O}_{2}$ generation. Similar to that found in vivo, BPA treatment also led to increased $\mathrm{H}_{2} \mathrm{O}_{2}$ generation in PCCL3. Nis mRNA levels were reduced and Duox2 mRNA levels were increased in BPA-exposed cells. To evaluate the importance of oxidative stress on BPA-induced Nis reduction, PCCL3 was treated with BPA in association to $\mathrm{N}$-acetylcysteine, an antioxidant, which reversed the effect of BPA on Nis. Our data suggest that BPA increases ROS production in thyrocytes, what could lead to oxidative damage thus possibly predisposing to thyroid disease.
\end{abstract} Key Words

$\begin{aligned} & \text { Key Words } \\ & \text { bisphenol A } \\ & \text { endocrine disruptor } \\ - & \text { reactive oxygen species } \\ - & \text { hydrogen peroxide } \\ - & \text { dual oxidase } \\ - & \text { thyroperoxidase } \\ - & \text { sodium-iodide symporter } \\ - & \text { iodide } \\ & \text { thyroid }\end{aligned}$

Endocrine Connections (2018) 7, 1196-1207

\section{Introduction}

Bisphenol A (BPA) is the most common monomer in polycarbonate plastic composition. It is used not only in the manufacture of polycarbonate-made products, such as beverage and food containers, but also in the synthesis of epoxy resins, found in the covering of canned food (1). When submitted to acidic $\mathrm{pH}$ or high temperature, the polymer undergoes breakdown of the ester bonds and
BPA can be released from the matrix, contaminating food, beverages and environment $(2,3)$.

BPA is an endocrine disruptor, being considered a selective estrogen receptor modulator (SERM) $(4,5)$, with important effects on reproductive function $(4,6)$. Besides that, BPA was shown to have positive association with serum TSH (7) and negative association with free T4 https://ec.bioscientifica.com

https://doi.org/10.1530/EC-18-0348 (c) 2018 The authors Published by Bioscientifica Ltd

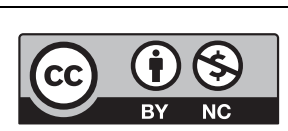

This work is licensed under a Creative Commons Attribution-NonCommercial 4.0 International License. 
levels (8), thus suggesting an impact also in thyroid axis. Furthermore, BPA has been shown to increase oxidative stress, leading to oxidative damage of proteins, lipids and nucleic acids in liver, central nervous system, reproductive system and kidney $(9,10)$.

For thyroid hormone (TH) synthesis, thyrocytes require iodide, which is transported through the basolateral plasma membrane by $\mathrm{Na}^{+} / \mathrm{I}^{-}$symporter (NIS) $(11,12,13)$. Thyroperoxidase (TPO), the key enzyme in TH biosynthesis, oxidizes iodide in the presence of $\mathrm{H}_{2} \mathrm{O}_{2}$, produced by dual oxidases (DUOX1 and DUOX2) $(14,15$, $16,17)$. However, an excessive production of hydrogen peroxide could lead to oxidative stress, since $\mathrm{H}_{2} \mathrm{O}_{2}$ is a reactive oxygen species (ROS) and thyroid gland damage $(18,19,20)$.

Since BPA has been shown to increase oxidative damage in several tissues and since thyrocytes are exposed to high levels of ROS due to TH biosynthesis, herein we hypothesized that BPA exposure could lead to an increased ROS production in thyrocytes thus affecting thyroid function. Therefore, our aim was to investigate the effect of BPA exposure on thyroid $\mathrm{H}_{2} \mathrm{O}_{2}$ production both in vivo and in vitro, besides the effect of BPA treatment on two proteins essential for TH synthesis: NIS and TPO.

\section{Materials and methods}

\section{Animals}

In all experiments, adult (4-5 months old) female Wistar rats were kept in controlled temperature $\left(22-25^{\circ} \mathrm{C}\right)$ animal room, with a 12-h light:12-h darkness cycle. We have chosen to study female rats since the prevalence of thyroid diseases is higher in women than in men $(20,21)$. Pelleted commercial chow (Paulinea, São Paulo, Brazil) and water were available ad libitum. The Institutional Committee for Use of Animals in Research approved the study (number: IBCCF167), and the procedures were in compliance with the International Guiding Principles for Biomedical Research Involving Animals of the Council for International Organizations of Medical Sciences (Geneva, Switzerland), and the guiding principles for care and use of animals from the American Physiological Society.

\section{Experimental design}

Animals were divided into two groups: Control (C) and bisphenol A (BPA). Control rats received vehicle (corn oil:isopropanol 20\% v/v) and BPA group received

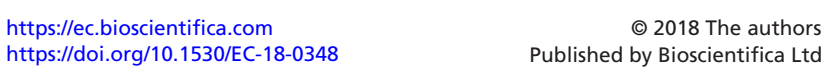

bisphenol A in the dose of $40 \mathrm{mg} / \mathrm{kg}$ body weight (BW) $(22,23,24)$, dissolved in vehicle. Both were administered daily by gavage. After 15 days of treatment, animals were weighed and killed. The dose of BPA was chosen based on the non-observable adverse effect level (NOAEL) for BPA, established in $50 \mathrm{mg} / \mathrm{kg} \mathrm{BW}(25,26)$. Thus, we decided to use a dose lower than NOAEL.

\section{Histological analysis}

The thyroids were collected and fixed in 10\% formaldehyde (pH 7.4) for $48 \mathrm{~h}$, followed by dehydration in ethanol (Vetec, Rio de Janeiro, Brazil) and clarification in xylene (Vetec, Rio de Janeiro, Brazil). Tissues were embedded in paraffin and cut at the thickness of $5 \mu \mathrm{m}$. Sections were stained with hematoxylin and eosin for topographic analysis according to Andrade et al. (27). High-resolution images $(1600 \times 1200$ pixels $)$ were obtained using digital camera (QImaging Retigar-2000R Fast 1394 Mono, Surrey BC, Canada) coupled to light microscope (Olympus BX50). High-quality images were captured with the QCapture Pro7 (QImaging).

\section{Radioiodide uptake}

We have previously shown that the measurement of radioiodide uptake $15 \mathrm{~min}$ after ${ }^{125} \mathrm{I}-\mathrm{NaI}$ administration (short term iodide uptake) reflects iodide transport through the sodium-iodide symporter without the influence of in vivo thyroid iodine organification activity (28). Thus, in order to evaluate the in vivo NIS function using thyroid radioiodine uptake measurements, the animals received Na- ${ }^{125}$ I (3700 Bq i.p., Amersham, Buckinghamshire, England) $15 \mathrm{~min}$ before decapitation. Thyroids were removed and weighed. The radioactivity of the thyroid glands was measured using a gamma counter (LKB), and the percentage of the ${ }^{125} \mathrm{I}$ in the gland relative to the total ${ }^{125}$ I injected was calculated. Results were expressed as relative to control.

\section{Thyroid peroxidase activity}

TPO extraction and activity measurement were performed as previously described $(28,29)$. Rat thyroids were minced and homogenized in $0.5 \mathrm{~mL}$ of $50 \mathrm{mM}$ Tris- $\mathrm{HCl}$ buffer, $\mathrm{pH}$ 7.2, containing $1 \mathrm{mM} \mathrm{KI}$, using an Ultra-Turrax homogenizer (Staufen, Germany). The homogenate was centrifuged at $100,000 \mathrm{~g}, 4^{\circ} \mathrm{C}$ for $1 \mathrm{~h}$. The pellet was suspended in $0.5 \mathrm{~mL}$ triton $(0.1 \% \mathrm{v} / \mathrm{v})$ and incubated at $4^{\circ} \mathrm{C}$ for $24 \mathrm{~h}$ to solubilize TPO. The suspension was 
centrifuged at $100,000 \mathrm{~g}, 4^{\circ} \mathrm{C}$ for $1 \mathrm{~h}$, and the supernatant containing solubilized TPO was used for the assays.

The assay mixture contained: $1.0 \mathrm{~mL}$ of freshly prepared $50 \mathrm{mmol} / \mathrm{L}$ sodium phosphate buffer, $\mathrm{pH} 7.4$, containing $24 \mathrm{mmol} / \mathrm{L} \mathrm{KI}$ and $11 \mathrm{mmol} / \mathrm{L}$ glucose, and increasing amounts of solubilized TPO. The final volume was adjusted to $2.0 \mathrm{~mL}$ with $50 \mathrm{mmol} / \mathrm{L}$ sodium phosphate buffer, $\mathrm{pH}$ 7.4 , and the reaction was started by the addition of $10 \mu \mathrm{L}$ of $0.1 \% \mathrm{w} / \mathrm{v}$ glucose oxidase (Boehringer Grade I). The increase in absorbance at $353 \mathrm{~nm}$ (tri-iodide production) was registered for $3 \mathrm{~min}$ on a Hitachi spectrophotometer (U-3300). The $\Delta \mathrm{A} 353 \mathrm{~nm} / \mathrm{min}$ was determined from the linear portion of the reaction curve and related to protein concentration. Protein concentration was determined by the Bradford assay (30). Results were expressed as relative to control.

\section{Thyroid $\mathrm{H}_{2} \mathrm{O}_{2}$ production}

$\mathrm{H}_{2} \mathrm{O}_{2}$ generation was quantified in thyroid particulate fractions by the Amplex red/horseradish peroxidase assay (Molecular Probes, Invitrogen), which detects the accumulation of a fluorescent oxidized product, as previously described $(18,31)$. To measure $\mathrm{H}_{2} \mathrm{O}_{2}$ production from particulate fraction, the excised thyroid glands remained at $4^{\circ} \mathrm{C}$ for $24 \mathrm{~h}$ in $50 \mathrm{mmol} / \mathrm{L}$ sodium phosphate buffer (pH 7.2) containing $0.25 \mathrm{~mol} / \mathrm{L}$ sucrose, $0.5 \mathrm{mmol} / \mathrm{L}$ dithiothreitol (DTT), $1 \mathrm{mmol} / \mathrm{L} \quad$ EGTA, $\quad 5 \mathrm{mg} / \mathrm{mL}$ aprotinin and $34.8 \mathrm{mg} / \mathrm{mL}$ phenylmethylsulphonyl fluoride (PMSF) before homogenization. Then, the homogenate was centrifuged at $100,000 \boldsymbol{g}$ for $35 \mathrm{~min}$ at $4^{\circ} \mathrm{C}$ and suspended in $0.25 \mathrm{~mL}$ of $50 \mathrm{mmol} / \mathrm{L}$ sodium phosphate buffer ( $\mathrm{pH} 7.2$ ) containing $0.25 \mathrm{~mol} / \mathrm{L}$ sucrose, $2 \mathrm{mmol} / \mathrm{L} \mathrm{MgCl}_{2}, 5 \mathrm{mg} / \mathrm{mL}$ aprotinin and $34.8 \mathrm{mg} / \mathrm{mL}$ PMSF (32). This particulate fraction was incubated in $150 \mathrm{mmol} / \mathrm{L}$ sodium phosphate buffer ( $\mathrm{pH} 7.4$ ) containing $100 \mathrm{U} / \mathrm{mL}$ superoxide dismutase (SOD) (Sigma), 0.5 U/mL horseradish peroxidase (HRP) (Roche), $50 \mu \mathrm{mol} / \mathrm{L}$ Amplex red (Molecular Probes), $1 \mathrm{mmol} / \mathrm{L}$ EGTA, with or without $1.5 \mathrm{mmol} / \mathrm{L} \mathrm{CaCl}_{2}$. Then, $0.1 \mathrm{mg} / \mathrm{mL} \mathrm{NADPH}$ was added to start the reaction and the fluorescence was immediately measured in a microplate reader (Victor X4; PerkinElmer, Norwalk, CT) at $30^{\circ} \mathrm{C}$, using excitation wavelength at $530 \mathrm{~nm}$ and emission wavelength at $595 \mathrm{~nm} . \mathrm{H}_{2} \mathrm{O}_{2}$ production was quantified using standard calibration curves (31).

The specific enzymatic activity was obtained as nmol of $\mathrm{H}_{2} \mathrm{O}_{2}$ per hour per milligram of protein ( $\mathrm{nmol} / \mathrm{h} / \mathrm{mg}$ protein) and calcium-dependent $\mathrm{H}_{2} \mathrm{O}_{2}$ generation was obtained by subtracting $\mathrm{H}_{2} \mathrm{O}_{2}$ generation in the absence of calcium from that obtained in the presence of calcium. Then, the results were expressed as relative to control. Protein concentration was determined by the Bradford assay (30).

\section{Radioimmunoassays}

Serum T3 and T4 were determined by specific coated tube RIA kits (MP Biomedicals, Orangeburg, NY, USA). Intra- and interassay coefficients of variation for T3 were $4.4-5.6 \%$ and 5.3-7.5\%, respectively, and sensitivity was $6.7 \mathrm{ng} / \mathrm{dL}$. For T4 intra-and interassay coefficients of variation were $3.3-8.1 \%$ and $5.3-11.4 \%$, respectively, and sensitivity was $0.76 \mu \mathrm{g} / \mathrm{dL}$. All procedures were performed following the fabricant recommendations.

\section{Cell culture}

Rat thyroid cell line PCCL3 (donated by Prof. Roberto Di Lauro, Stazione Zoologica Anton Dohrn) was maintained in Coon's modified Ham's F-12 medium (HiMedia Laboratories, Mumbai, India), which contains $10 \mathrm{mM}$ glucose, supplemented with $5 \% \mathrm{v} / \mathrm{v}$ fetal bovine serum and a six-hormone mixture $(1 \mathrm{mIU} / \mathrm{mL} \mathrm{TSH}, 10 \mathrm{mg} / \mathrm{mL}$ insulin, $5 \mathrm{mg} / \mathrm{mL}$ transferrin, $10 \mathrm{nM}$ hydrocortisone, $10 \mathrm{ng} / \mathrm{mL}$ somatostatin, and $10 \mathrm{ng} / \mathrm{mL}$ glycyl-L-histidylL-lysine acetate) and maintained in a humidified 5\% v/v $\mathrm{CO}_{2}$ incubator at $37^{\circ} \mathrm{C}$.

\section{Cell treatment and cell viability assay}

In order to evaluate the possible toxic effect of bisphenol A on PCCL3 cells, we treated the cells with different concentrations of BPA $\left(10^{-9}, 10^{-7}, 10^{-5}\right.$ and $10^{-3} \mathrm{~mol} / \mathrm{L}$ $\mathrm{BPA}$ ) or vehicle (ethanol $0.1 \% \mathrm{v} / \mathrm{v}$ ) for $24 \mathrm{~h}$. As an index of cell viability, we used the commercially available MTT (3-(4,5-dimethylthiazol-2-yl)-2,5-diphenyltetrazolium bromide) assay (Sigma-Aldrich), according to the manufacturer's recommendations. This is a colorimetric assay to determine the number of viable cells. The assay is based on the cellular conversion of the tetrazolium salt into formazan that is soluble in tissue culture medium, and it is measured directly at $490 \mathrm{~nm}$ in 96-well assay plates. Absorbance is directly proportional to the number of living cells in culture. After treatment, cells were stained with MTT $(0.5 \mathrm{mg} / \mathrm{mL})$ for $3 \mathrm{~h}$ at $37^{\circ} \mathrm{C}$ in a humidified $5 \% \mathrm{CO}_{2}$ atmosphere. Then, cells were lysed with DMSO (P A). All determinations were done in triplicates. Since we did not find reduction of cell viability with $10^{-9} \mathrm{~mol} / \mathrm{L} \mathrm{BPA}$, suggesting that BPA is not toxic for 
PCCL3 cells at this concentration, we decided to perform the next experiments using this concentration. Moreover, literature data suggest that the concentration of BPA in the serum is in nmol/L range in humans $(33,34)$. Results were expressed as relative to control.

In order to evaluate the involvement of the prooxidant effect of BPA on Nis and Tpo mRNA regulation, PCCL3 cells were incubated for $24 \mathrm{~h}$ with or $10^{-9} \mathrm{~mol} / \mathrm{L}$ BPA in association or not with $1 \mathrm{mmol} / \mathrm{L} \mathrm{N}$-acetylcysteine (NAC), which was added $30 \mathrm{~min}$ before BPA addition (35).

\section{Real-time PCR}

Total RNA was extracted using the RNeasy Plus Mini Kit (Qiagen), following the manufacturer's instructions. After DNase treatment, reverse transcription was followed by real-time PCR, as previously described (36). Specific oligonucleotides, as described in Table 1, were purchased from Applied Biosystems (Foster City, California, USA). GAPDH was used as internal control. Results were expressed as relative to control.

\section{$\mathrm{H}_{2} \mathrm{O}_{2}$ production in intact cells}

Extracellular $\mathrm{H}_{2} \mathrm{O}_{2}$ generation was quantified by the Amplex red/horseradish peroxidase assay, which detects the accumulation of a fluorescent oxidized product, as previouslydescribed $(18,31)$. Cells $\left(1 \times 10^{5}\right)$ inDulbecco'sPBS (D-PBS) containing $\mathrm{CaCl}_{2}$ and $\mathrm{MgCl}_{2}$ were incubated with D-glucose $(1 \mathrm{mg} / \mathrm{mL})$, superoxide dismutase $(100 \mathrm{U} / \mathrm{mL})$,

Table 1 Primers used for real-time PCR assay.

\begin{tabular}{llll}
\hline Nis & Forward & 5' GCT CAT CCT GAA CCA AGT GA 3' \\
& Reverse & 5' ACG AGC ATT ACC ACA ACC TG 3' \\
Duox1 & Forward & 5' ATT TCT TGG GAG GTA CAG CG 3' \\
& Reverse & 5' GTT AGG CAG GTA GGG TTC TTT C 3' \\
Duoxa1 & Forward & 5' TGA CCA GCT TAT TCA TCG GG 3' \\
& Reverse & 5' CTG TGA GGG TGA TGT TGA GTC 3' \\
Duox2 & Forward & 5' AGG AGT GGC ATA AGT TTG AGG 3' \\
& Reverse & 5' CCT TGT CAC CCA GAT GAA GTA G 3' \\
Duoxa2 & Forward & 5' TGG TAT TCT TGT CCT TGG CTG 3' \\
& Reverse & 5' GGA GGT ACT GAA GGC TTT GTA G 3' \\
Tpo & Forward & 5' GAA TGA GGA ACT GAC CGA GAG 3' \\
& Reverse & 5' TGA CAA GCC ACA GAA CTC TC 3' \\
B-Tsh & Forward & 5' TCT GCG CTG GGT ATT GTA TG 3' \\
& Reverse & 5' CGG TAT TTC CAC CGT TCT GT 3' \\
Gapdh & Forward & 5' TGA TTC TAC CCA CGG GAA GT 3' \\
& Reverse & 5' AGC ATC ACC CCA TTT GAT GT 3' \\
\hline
\end{tabular}

$\beta$-Tsh, beta subunit of thyroid stimulating hormone (TSH); Duox 1 , dual oxidase 1; Duox2, dual oxidase 2; Duoxa1, dual oxidase maturation factor 1; Duoxa2, dual oxidase maturation factor 2; Gapdh, glyceraldehyde 3-phosphate dehydrogenase; Nis, sodium iodide symporter; Tpo, thyroperoxidase. horseradish peroxidase $(0.5 \mathrm{U} / \mathrm{mL})$, and Amplex red $(50 \mu \mathrm{mol} / \mathrm{L})$, in the presence or absence of $1 \mu \mathrm{mol} / \mathrm{L}$ ionomycin, a calcium ionophore, since DUOX, the enzyme responsible for $\mathrm{H}_{2} \mathrm{O}_{2}$ generation associated to $\mathrm{TH}$ synthesis, is a calcium-dependent NADPH oxidase (19). The fluorescence was immediately measured in a microplate reader (Victor3, Perkin Elmer) for $30 \mathrm{~min}$ (excitation wavelength $=530 \mathrm{~nm}$ and emission wavelength $=595 \mathrm{~nm}) . \mathrm{H}_{2} \mathrm{O}_{2}$ generation was determined using standard calibration curves. Results were obtained as nmols of $\mathrm{H}_{2} \mathrm{O}_{2}$ per hour per $10^{5}$ cells. In order to obtain calcium-dependent $\mathrm{H}_{2} \mathrm{O}_{2}$ generation, which is associated to DUOX activity, $\mathrm{H}_{2} \mathrm{O}_{2}$ generation obtained in the presence of ionomycin was subtracted by that found in the absence of ionomycin. Then, results were expressed as relative to control.

\section{Statistical analyses}

All the results are expressed as mean \pm S.E.M. and were analyzed by Unpaired $t$-test. Experiments were performed at least twice and at least two animals/cell replicates per group per experiment were used. Results of cell viability assay were analyzed by One-way ANOVA followed by the Newman-Keuls multiple comparison test, since there were more than two groups. Statistical analyses were conducted using the software GraphPad Prism (version 5, GraphPad Software Inc, San Diego, California), and the level of significance was established at $P<0.05$.

\section{Results}

\section{Body and thyroid weight}

BPA treatment led to a slight though significant increase in BW, as shown in Table 2. This result suggest that the energetic homeostasis was affected by BPA what is in accordance with the well-known obesogenic effect of BPA (37). On the other hand, absolute and relative thyroid weight remained unchanged (Table 2).

\section{Histological analysis}

The thyroid glands from control rats showed a normal tissue organization: follicles with simple cuboidal epithelial cells surrounding a cavity rich in eosinophilic material or colloid, besides a rich vascular stroma (Fig. 1). In BPA-treated group, we observed many hypoactive follicles, with squamous epithelium surrounded by interfollicular connective tissue. 
Table 2 Effect of BPA treatment on body weight, absolute and relative thyroid weight of female rats.

\begin{tabular}{|c|c|c|c|}
\hline Group & Body weight (g) & Absolute thyroid weight (mg) & Relative thyroid weight (mg/100 g BW) \\
\hline Control & $218.6 \pm 3.4$ & $17.3 \pm 0.9$ & $7.8 \pm 0.4$ \\
\hline BPA & $228.0 \pm 3.1 *$ & $16.9 \pm 0.8$ & $7.7 \pm 0.3$ \\
\hline
\end{tabular}

Female Wistar rats were treated with vehicle (Control, corn oil:isopropanol $20 \% \mathrm{v} / \mathrm{v}$ ) or bisphenol A (BPA, $40 \mathrm{mg} / \mathrm{kg}$ BW), orally by gavage, daily for 15 days ( $n=16$ per group, ${ }^{*} P<0.05$ vs control group).

Thyroid iodide uptake, TPO activity and $\mathrm{H}_{2} \mathrm{O}_{2}$ generation in rats

Since iodide is an essential element for TH biosynthesis (12), we have evaluated the effect of BPA on in vivo thyroid radioiodide uptake. In fact, BPA treatment significantly decreased thyroid iodide uptake (Fig. 2A).
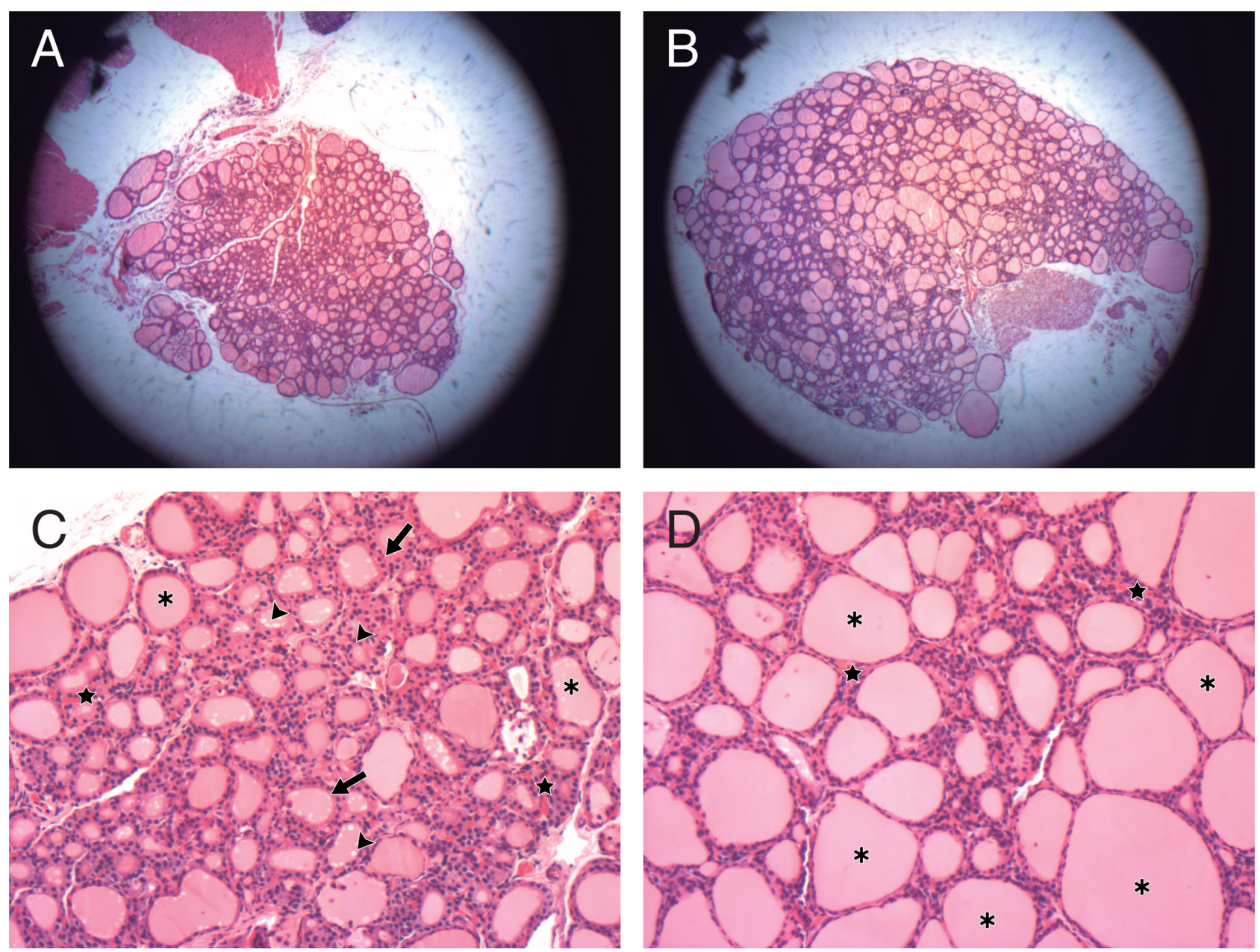

TH synthesis requires not only iodide uptake, but also iodide oxidation and organification, reactions catalyzed by thyroperoxidase, in the presence of $\mathrm{H}_{2} \mathrm{O}_{2}$ (38). We have thus evaluated TPO activity and $\mathrm{H}_{2} \mathrm{O}_{2}$ generation. BPA led to a significant reduction of TPO activity (Fig. 2B), similarly to that found for NIS. Therefore, two fundamental steps for TH biosynthesis

Figure 1

Photomicrographs of thyroid gland histological sections of rats exposed to BPA. Hematoxylin and eosin staining. Female Wistar rats were treated with vehicle (Control, corn oil:isopropanol 20\%) or bisphenol A (BPA, $40 \mathrm{mg} / \mathrm{kg}$ BW), orally by gavage, daily for 15 days. (A) Control: lobe of the thyroid showing follicles of different size and activity status (normo, hypo and hyperactive). (B) BPA: lobe showing large number of hypoactive follicles. (C) Control: note the predominantly follicular structures, circled by a simple epithelium (arrow), containing eosinophilic material (colloid, asterisk), areas of colloid reabsorption (arrowhead) and interfollicular rich vascularized stroma (star). (D) BPA: note many hypoactive follicles with squamous epithelium (asterisk) and interfollicular connective tissue (star). Magnification of $A$ and $B=20 \times$ and $C$ and $D=200 \times . N=3$ per group.

https://ec.bioscientifica.com

https://doi.org/10.1530/EC-18-0348 (c) 2018 The authors Published by Bioscientifica Ltd 

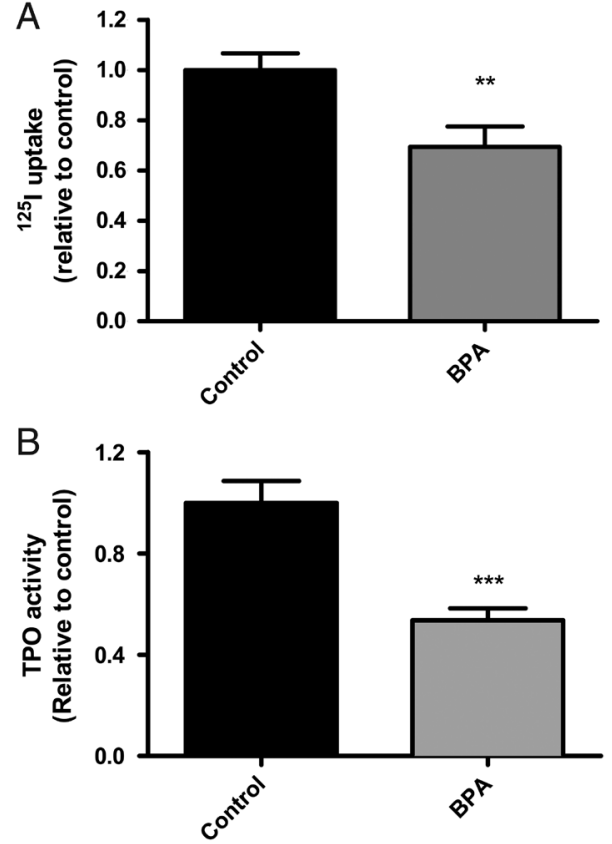

\section{Figure 2}

Effect of BPA exposure on thyroid radioiodide uptake and thyroperoxidase (TPO) activity. Female Wistar rats were treated with vehicle (Control, corn oil:isopropanol 20\%) or bisphenol A (BPA, $40 \mathrm{mg} / \mathrm{kg}$ BW), orally by gavage, daily for 15 days. (A) Radioiodide was

administered to rats (i.p.) and $15 \mathrm{~min}$ later they were killed, thyroids were removed, weighed and the radioactivity was measured. (B) Thyroids were processed and iodide oxidation TPO activity was measured as described in 'Methods' section. Results are expressed as relative to control (control, $n=10$ and BPA, $n=9 ; * * P<0.01$ vs control and $* * * P<0.001$ vs control).

were affected by BPA treatment: iodide uptake and TPO activity.

Thyroid $\mathrm{H}_{2} \mathrm{O}_{2}$ generation in the absence of calcium remained unchanged (Fig. 3A), while thyroid $\mathrm{H}_{2} \mathrm{O}_{2}$ generation in the presence of calcium was increased in BPA-treated group (Fig. 3B). Thus, calcium-dependent $\mathrm{H}_{2} \mathrm{O}_{2}$ generation was significantly increased in the thyroid of rats treated with BPA (Fig. 3C). Since $\mathrm{H}_{2} \mathrm{O}_{2}$ is a ROS, the increment in $\mathrm{H}_{2} \mathrm{O}_{2}$ levels could lead to an enhancement of oxidative stress in the gland, especially because TPO activity, which consumes $\mathrm{H}_{2} \mathrm{O}_{2}$, is reduced.

\section{Serum total T4 and T3 and pituitary $\beta$-Tsh mRNA}

Since thyroid iodide uptake and thyroperoxidase activity were reduced by BPA treatment, we next evaluated $\mathrm{TH}$ levels. Surprisingly, we have found an increment in T4 levels in the serum of BPA-exposed rats, while T3 remained unchanged (Table 3). Thus, despite the reduction of TPO activity found in the dosage in vitro, it is possible that, in vivo, the greater availability of the TPO cofactor, $\mathrm{H}_{2} \mathrm{O}_{2}$,
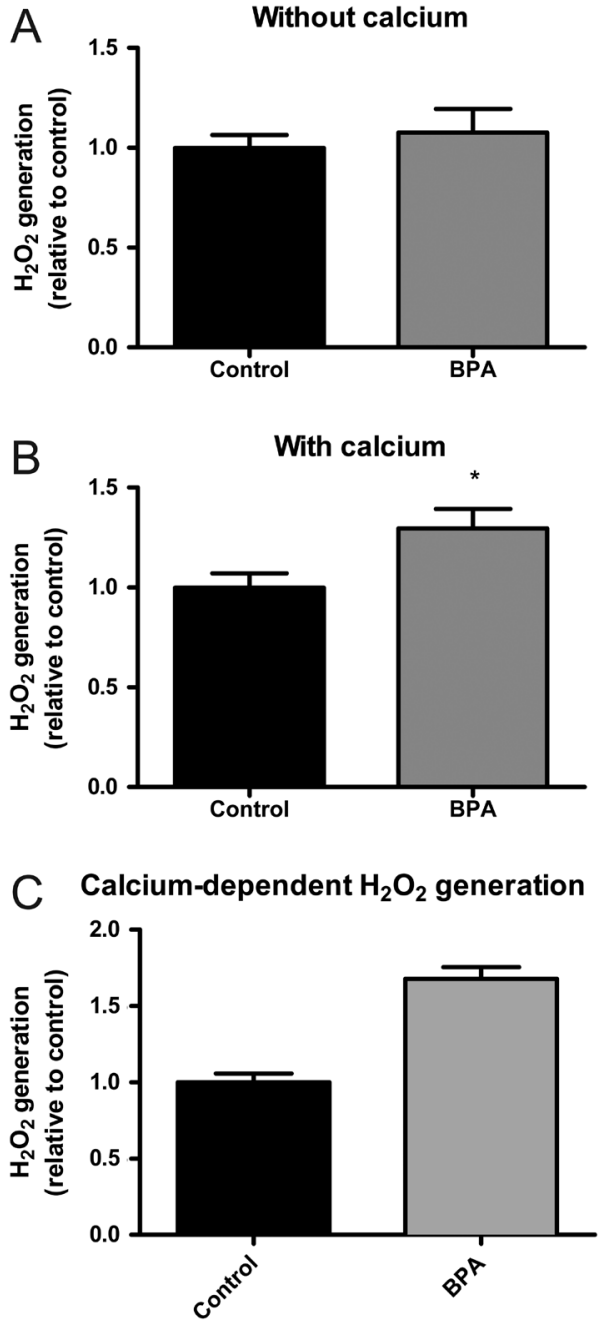

Figure 3

Effect of BPA exposure on thyroid $\mathrm{H}_{2} \mathrm{O}_{2}$ generation. Female Wistar rats were treated with vehicle (Control, corn oil:isopropanol $20 \%$ ) or bisphenol A (BPA, $40 \mathrm{mg} / \mathrm{kg} \mathrm{BW),} \mathrm{orally} \mathrm{by} \mathrm{gavage,} \mathrm{daily} \mathrm{for} 15$ days. Thyroid $\mathrm{H}_{2} \mathrm{O}_{2}$ generation was measured by Amplex red method, as described in methods. Activity was measured in the absence (A) and in the presence $(B)$ of calcium, since dual oxidase is a calcium-dependent NADPH oxidase and calcium-dependent $\mathrm{H}_{2} \mathrm{O}_{2}$ generation (C) was obtained subtracting the activity in the presence of calcium by that obtained in the absence of calcium. Results are expressed as relative to control (control, $n=10$ and BPA, $n=9 ; * P<0.05$ vs control and $* * * P<0.001$ vs control).

has led to the increased T4 synthesis. In accordance to the increased serum T4, we have found a significant reduction of Tsh beta chain mRNA levels in the pituitary of the rats treated with BPA (Table 3).

\section{PCCL3 cell viability}

Since the changes in proteins involved in TH synthesis observed in vivo could be due to a direct effect of BPA or 
Table 3 Effect of BPA treatment on serum total T4 and T3 concentrations and mRNA levels of TSH beta chain in pituitary of female rats.

\begin{tabular}{|c|c|c|c|}
\hline Group & Total T4 ( $\mu \mathrm{g} / \mathrm{dL})$ & Total T3 (ng/dL) & Pituitary mRNA levels of $\boldsymbol{\beta}$-TSH (relative to control) \\
\hline Control & $3.6 \pm 0.2$ & $50.7 \pm 3.4$ & $1.0 \pm 0.2$ \\
\hline BPA & $4.8 \pm 0.3 *$ & $59.0 \pm 5.3$ & $0.5 \pm 0.1 *$ \\
\hline
\end{tabular}

Female Wistar rats were treated with vehicle (Control, corn oil:isopropanol $20 \% \mathrm{v} / \mathrm{v}$ ) or bisphenol A (BPA, $40 \mathrm{mg} / \mathrm{kg}$ BW), orally by gavage, daily for 15 days ( $n=10$ per group for serum total T4 and total T3 and $n=4$ per group for pituitary $\beta$-TSH mRNA levels, ${ }^{*} P<0.05$ vs control group).

could be related to hormonal changes caused by BPA, we next evaluated the direct effect of BPA on thyrocytes, using the non-tumor rat thyroid cell line PCCL3 as a model. However, since BPA could be toxic for PCCL3, we have first evaluated the effect of BPA on cell viability. In fact, at the concentration $10^{-3} \mathrm{~mol} / \mathrm{L}, \mathrm{BPA}$ seems to be toxic for PCCL3, significantly reducing its viability (Fig. 4A). Surprisingly, $10^{-7} \mathrm{~mol} / \mathrm{L}$ BPA significantly increased cell viability, suggesting that this compound could increase cell proliferation, reduce cell death or both. Since $10^{-9} \mathrm{~mol} / \mathrm{L}$ BPA did not affect cell viability and since this concentration is in the range of BPA concentration found
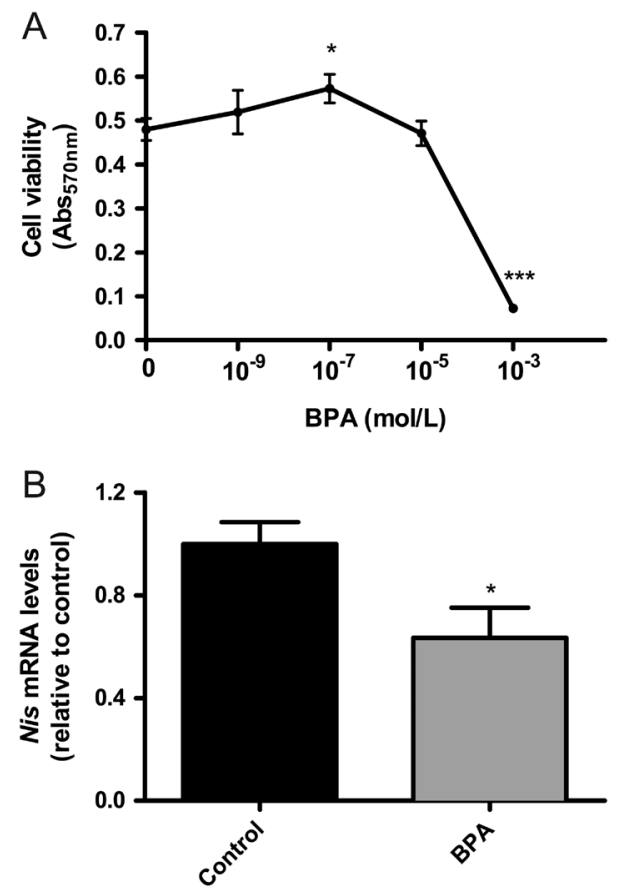

\section{Figure 4}

Effect of BPA on cell viability and sodium-iodide symporter (Nis) mRNA levels in PCCL3 cells. (A) Rat thyroid cell line PCCL3 was incubated with vehicle (control, $0.1 \%$ ethanol) or different BPA concentrations $\left(10^{-9}\right.$, $10^{-7}, 10^{-5}$ and $10^{-3} \mathrm{~mol} / \mathrm{L}$ BPA) and $24 \mathrm{~h}$ later cell viability was assayed by MTT, as described in methods ( $n=12$ per experimental condition; ${ }^{*} P<0.05$ vs control and $* * * P<0.001$ vs control). (B) PCCL3 cells were incubated with vehicle (control, $0.1 \%$ ethanol) or $10^{-9} \mathrm{~mol} / \mathrm{L}$ BPA and Nis mRNA levels were evaluated by qRT-PCR, as described in methods. Results are expressed as relative to control (control, $n=6$; BPA, $n=4 ; * P<0.05$ vs control).

https://ec.bioscientifica.com
https://doi.org/10.1530/EC-18-0348

in human serum $(33,34)$, we decided to use $10^{-9} \mathrm{~mol} / \mathrm{L}$ BPA for the next experiments.

\section{Nis mRNA levels in PCCL3}

Since in vivo data have shown an inhibitory effect of BPA on thyroid iodide uptake, which is mediated by NIS, we have next evaluated Nis mRNA levels in PCCL3 cells treated with BPA. We have found a reduction of Nis mRNA levels in BPA-treated cells (Fig. 4B). Thus, BPA seems to act by transcriptional mechanism to regulate Nis mRNA levels.

\section{$\mathrm{H}_{2} \mathrm{O}_{2}$ generation and Duox and Duoxa mRNA levels in PCCL3}

Since in vivo data found herein showed an increment of thyroid $\mathrm{H}_{2} \mathrm{O}_{2}$ generation and since it has been shown that ROS have an inhibitory effect on NIS (39), we have then evaluated the effect of BPA on $\mathrm{H}_{2} \mathrm{O}_{2}$ generation and on Duox1, Duox2, Duoxa1 and Duoxa2 mRNA levels. DUOX1 and DUOX2 are calcium-dependent NADPH oxidases responsible for $\mathrm{H}_{2} \mathrm{O}_{2}$ generation associated to TH
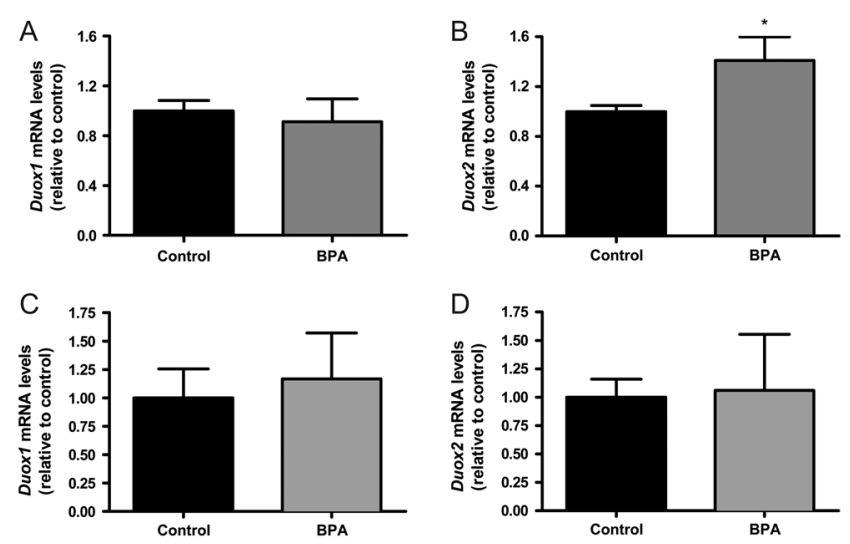

\section{Figure 5}

Effect of BPA on Duox1, Duox2, Duoxa1 and Duoxa2 mRNA levels in PCCL3 cells. PCCL3 cells were incubated with vehicle (control, $0.1 \%$ ethanol) or $10^{-9} \mathrm{~mol} / \mathrm{L}$ BPA and $24 \mathrm{~h}$ later mRNA levels of (A) Duox1; (B) Duox2; (C) Duoxa1 and (D) Duoxa2 were evaluated by qRT-PCR, as described in 'Methods' section. Results are expressed as relative to control (control, $n=6$; BPA, $n=4$; ${ }^{*}<<0.05$ vs control).

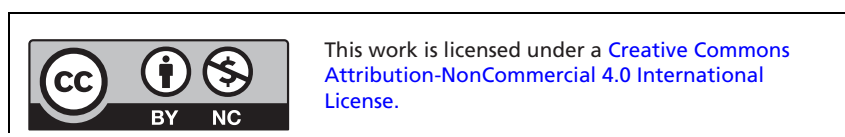


A

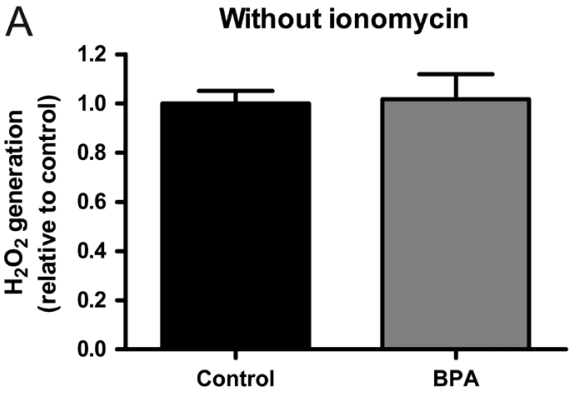

B

With ionomycin

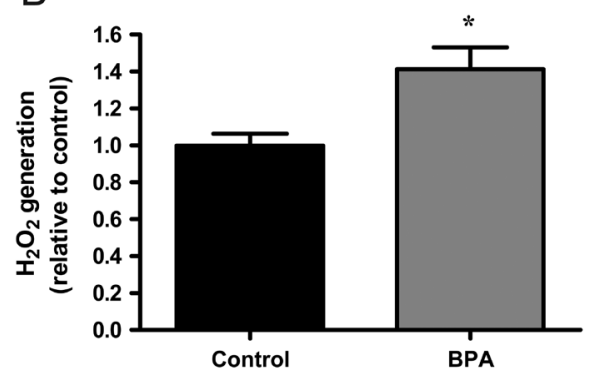

C Calcium-dependent $\mathrm{H}_{2} \mathrm{O}_{2}$ generation

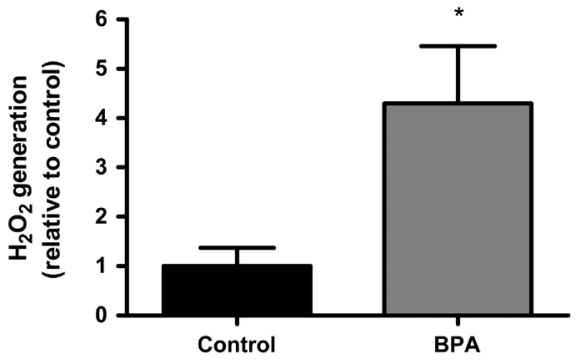

Figure 6

Effect of BPA on extracellular $\mathrm{H}_{2} \mathrm{O}_{2}$ generation in PCCL3 cells. PCCL3 cells were incubated with vehicle (control, $0.1 \%$ ethanol) or $10^{-9} \mathrm{~mol} / \mathrm{L}$ BPA and $24 \mathrm{~h}$ later, extracellular $\mathrm{H}_{2} \mathrm{O}_{2}$ generation was measured by Amplex red method, as described in methods. Activity was measured in the absence $(A)$ and in the presence $(B)$ of ionomycin, a calcium ionophore, since dual oxidase is a calcium-dependent NADPH oxidase, and calciumdependent $\mathrm{H}_{2} \mathrm{O}_{2}$ generation (C) was obtained subtracting the activity in the presence of calcium by that obtained in the absence of calcium. Results are expressed as relative to control (control, $n=9$; BPA, $n=9$; $* P<0.05$ vs control)

biosynthesis $(15,16)$ and DUOXA1 and DUOXA2 are the maturation factors necessary for full DUOX1 and DUOX2 activities, respectively (40). In fact, mutations in Duox2 have been associated to dyshormonogenesis and goiter $(16,41)$. Duox 2 mRNA levels showed a significant increase in BPA-treated cells, (Fig. 5B), while Duox1 mRNA levels remained unchanged (Fig. 5A). Moreover, mRNA levels of both Duoxa1 (Fig. 5C) and Duoxa2 (Fig. 5D) were not altered by BPA treatment.

$\mathrm{H}_{2} \mathrm{O}_{2}$ generation in the absence of ionomycin remained unchanged (Fig. 6A), while $\mathrm{H}_{2} \mathrm{O}_{2}$ generation in the presence of ionomycin was increased by BPA (Fig. 6B).

https://ec.bioscientifica.com
https://doi.org/10.1530/EC-18-0348 2018 The authors
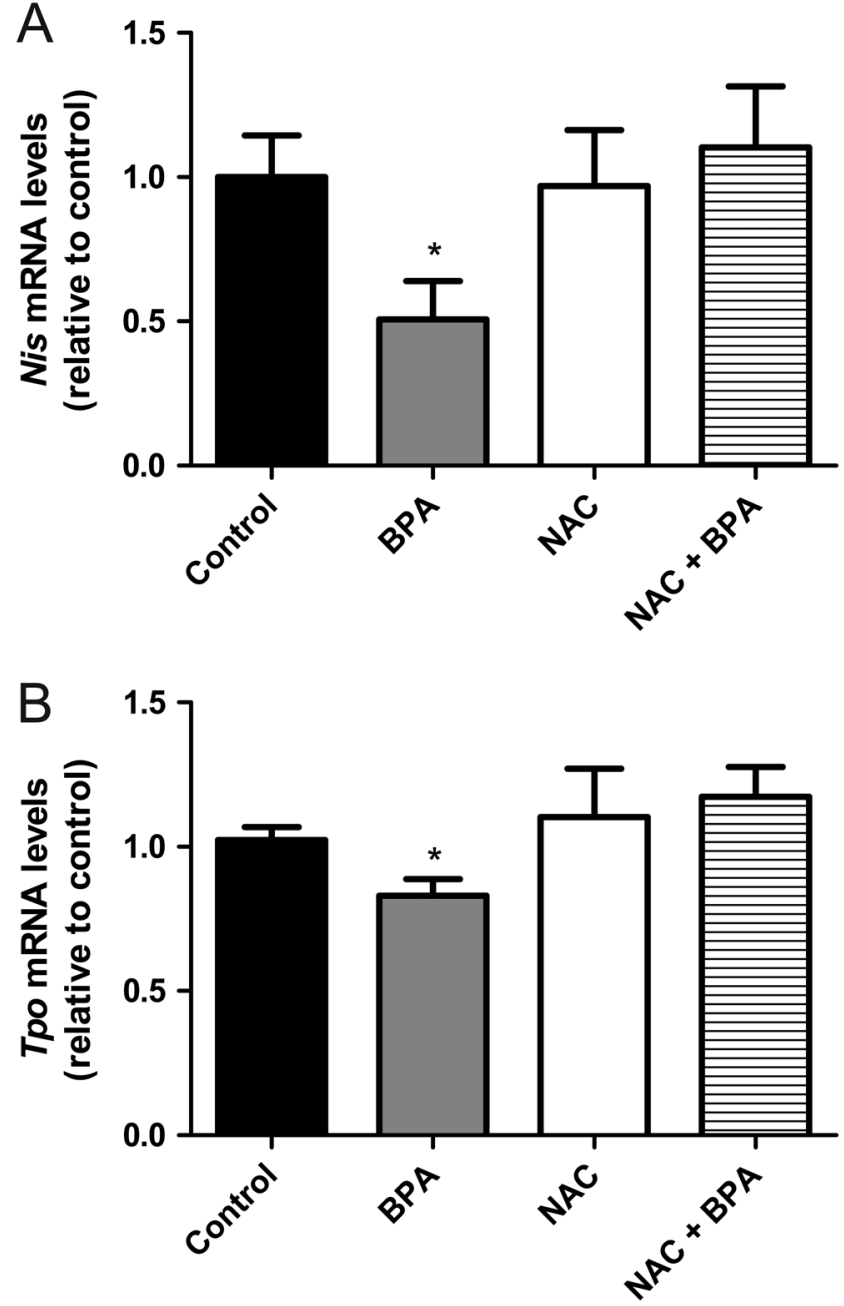

Figure 7

Effect of BPA and NAC on Nis and Tpo mRNA levels in PCCL3 cells. PCCL3 cells were incubated with vehicle (control, $0.1 \%$ ethanol) or $10^{-9} \mathrm{~mol} / \mathrm{L}$ BPA, with or without $1 \mathrm{mmol} / \mathrm{L}$ NAC, and $24 \mathrm{~h}$ later mRNA levels of (A) Nis and (B) Tpo were evaluated by qRT-PCR, as described in methods. Results are expressed as relative to control (NIS: control, $n=5$; BPA, $n=5$; NAC, $n=6$; NAC +BPA, $n=6$; TPO: control, $n=6$; BPA, $n=5$; NAC, $n=6$; NAC + BPA, $n=6 ; * P<0.05$ vs control).

Calcium-dependent extracellular $\mathrm{H}_{2} \mathrm{O}_{2}$ generation was significantly increased in BPA-treated cells (Fig. 6C), thus suggesting that the stimulatory effect of BPA on thyrocyte $\mathrm{H}_{2} \mathrm{O}_{2}$ generation occurs not only in vivo but also in vitro, what could be deleterious to the thyroid gland since $\mathrm{H}_{2} \mathrm{O}_{2}$ is a ROS.

\section{Effect of BPA on Nis and Tpo mRNA levels is reversed by NAC}

Since BPA seems to have an inhibitory effect on NIS and TPO, besides increasing ROS production, we have next evaluated the involvement of oxidative stress in the 
effect of BPA. As shown in Fig. 7A, co-incubation of BPAtreated cells with $\mathrm{N}$-acetylcysteine (NAC), an antioxidant, prevented the inhibitory effect of BPA on Nis expression. In a similar way, NAC also prevented the reduction of Tpo mRNA levels by BPA (Fig. 7B). Thus, our result suggests that the inhibitory effect of BPA on Nis and Tpo expression might involve increased oxidative stress.

\section{Discussion}

BPA has been shown to be a widespread environmental contaminant and can be found in the serum and urine of both wildlife (42) and humans (43). This exposition affects many organs and systems, including reproductive system (44), nervous system (45) and thyroid (46). Despite that, data regarding the impact of BPA on thyroid redox homeostasis and its consequences on proteins involved in TH synthesis remains elusive.

TH synthesis requires hydrogen peroxide generation, since $\mathrm{H}_{2} \mathrm{O}_{2}$ is the essential cofactor for TPO (47). In vivo, DUOX is the enzyme responsible for $\mathrm{H}_{2} \mathrm{O}_{2}$ generation associated to TH biosynthesis (16). Since DUOX is a calcium-dependent NADPH oxidase (48), herein we have evaluated thyroid $\mathrm{H}_{2} \mathrm{O}_{2}$ generation both in the presence and in the absence of calcium. In fact, thyroid calciumdependent $\mathrm{H}_{2} \mathrm{O}_{2}$ generation was increased in BPA-treated group, suggesting that the gland could be exposed to an increased oxidative stress. The reduction in TPO activity reinforces the idea of an unbalance in redox homeostasis, since TPO is an important consumer of the $\mathrm{H}_{2} \mathrm{O}_{2}$ generated by DUOX (49). Moreover, TPO has been shown to be sensitive to the oxidative stress induced in conditions of high DUOX activity (31). Besides, there is a negative correlation between DUOX and TPO in human thyroid nodular lesions and in experimental model of type 1 diabetes mellitus $(18,50)$. Therefore, increased $\mathrm{H}_{2} \mathrm{O}_{2}$ generation in the thyroid of rats exposed to BPA, due to a higher DUOX activity, might have induced a decrease in TPO activity through the oxidation of this enzyme.

In zebrafish embryo-larvae, tpo mRNA levels remained unchanged after BPA exposition (51), and TPO activity from rat thyroid microsomes was shown to be unaffected by incubation with BPA in vitro (52). On the other hand, in the rat thyroid cell line FRTL-5, BPA reduced Tpo mRNA levels (52). Therefore, besides the oxidation of TPO protein due to increased ROS production, BPA treatment could also reduce TPO activity due to the downregulation of Tpo gene expression.
Despite the reduced in vitro TPO activity found in rats treated with BPA, T4 levels were not reduced in this group, in fact T4 was increased. The greater availability of TPO cofactor $\mathrm{H}_{2} \mathrm{O}_{2}$ in the thyroid gland of BPA-treated animals might have contributed to the increment in serum $\mathrm{T} 4$ levels in this group.

BPA has been shown to increase oxidative stress in some tissues, such as testis (53), liver (54) and heart (55). However, to our knowledge, this is the first report describing the effect of BPA increasing thyroid $\mathrm{H}_{2} \mathrm{O}_{2}$ generation. It was previously shown that the thyroid gland is exposed to a higher risk of oxidative DNA damage when compared to other tissues, due to the necessity of $\mathrm{H}_{2} \mathrm{O}_{2}$ generation during $\mathrm{TH}$ biosynthesis (56). Therefore, the increment in ROS generation due to BPA exposure could predispose the gland to oxidative stress and thus to thyroid diseases.

NIS has been shown to be sensitive to $\operatorname{ROS}(57,58$, 59). Since BPA induced an increment in $\mathrm{H}_{2} \mathrm{O}_{2}$ generation, we have also evaluated NIS-mediated thyroid iodide uptake. In fact, in vivo thyroid iodide uptake was reduced by BPA treatment, which could be related to an increased oxidative stress or could be related to a direct effect of BPA regulating NIS expression. Then, we have evaluated BPA effect on Nis mRNA levels. In fact, the treatment of the rat thyroid cell line PCCL3 cells with $10^{-9} \mathrm{M}$ BPA led to a significant reduction of Nis expression.

In zebrafish embryo-larvae, the treatment with BPA did not affect nis mRNA levels (51), while in rat thyroid cell line FRTL5, BPA was shown to reduce iodide uptake, besides reducing Nis expression (52). Therefore, at least in rats, BPA seems to be able to reduce both NIS expression and function, what is in accordance to our data. Since BPA is a xenoestrogen (60), it is possible that the effect of BPA downregulating NIS is due to its estrogenic activity, since estrogen has been shown to downregulate NIS in FRTL-5 cells (61). On the other hand, the possible estrogenic effect of BPA regulating NIS expression does not exclude the possibility that the increased ROS production could also affect NIS expression and function, so we have also evaluated $\mathrm{H}_{2} \mathrm{O}_{2}$ generation in PCCL3 exposed to BPA.

We have observed that, similarly to that found in vivo, BPA treatment has also increased calciumdependent extracellular $\mathrm{H}_{2} \mathrm{O}_{2}$ generation in vitro. This effect could be related to the increased Duox2 expression found herein, which has been shown to be the DUOX isoform essential to hormonogenesis, since mutation in this enzyme leads to hypothyroidism $(41,62)$. On the other hand, it is known that the main isoform responsible

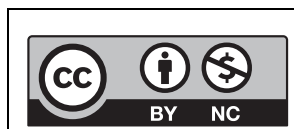

This work is licensed under a Creative Commons Attribution-NonCommercial 4.0 International License. 
for $\mathrm{H}_{2} \mathrm{O}_{2}$ generation in PCCL3 cells is DUOX1 (63). Another possibility is the regulation of DUOX activity at post-transcriptional level by BPA. Both DUOX1 and DUOX2 have been described to be regulated by cascades of phosphorylation (64). Even though BPA can activate nuclear estrogen receptor, this endocrine disruptor is known to be more potent acting by non-nuclear estrogen receptors (65). Therefore, BPA could act at membrane estrogen receptors, activating phosphorylation cascades and thus activating DUOX and increasing $\mathrm{H}_{2} \mathrm{O}_{2}$ generation in PCCL3. In fact, estrogen has been shown to increase ROS production in PCCL3 cells, which express both nuclear and membrane estrogen receptors (66). However, future studies are needed to elucidate the mechanism of BPA action regulating ROS production by thyrocytes.

The effect of BPA downregulating Nis and Tpo requires increased oxidative stress, since NAC was able to prevent the reduction of Nis and Tpo mRNA levels induced by BPA in PCCL3. NAC has previously been shown to prevent oxidative damage induced by BPA in Sertoli cells (67) and rat brain (68). Thus, BPA seem to cause a redox imbalance in the thyrocytes, disrupting the normal functioning of the thyroid gland.

\section{Conclusion}

The present study showed that the exposition of thyrocytes to the endocrine disruptor bisphenol A can increase ROS production, both in vivo and in vitro. Moreover, BPA decreased thyroid iodide uptake and thyroperoxidase activity, two essential steps for TH synthesis. This effect might be related to an increased oxidative stress since NAC could prevent the reduction of Tpo and Nis mRNA levels induced by BPA in PCCL3. The enhancement of ROS production by thyrocytes related to the exposition to BPA could lead to oxidative damage of the gland, thus predisposing individuals exposed to BPA to thyroid diseases.

\section{Declaration of interest}

The authors declare that there is no conflict of interest that could be perceived as prejudicing the impartiality of the research reported.

\section{Funding}

This work was supported by Fundação de Amparo à Pesquisa do Rio de Janeiro (FAPERJ), Conselho Nacional de Desenvolvimento Científico e Tecnológico (CNPq) and Coordenação de Aperfeiçoamento de Pessoal de Nível Superior (CAPES).

\section{Acknowledgments}

The authors are grateful for the technical assistance of Norma Lima de Araújo Faria, Wagner Nunes Bezerra and José Humberto Tavares de Abreu. They are grateful to Fabio Hecht Castro Medeiros for the assistance in the treatment of the figures.

\section{References}

1 Krishnan AV, Stathis P, Permuth SF, Tokes L \& Feldman D. Bisphenol A: an estrogenic substance is released from polycarbonate flasks during autoclaving. Endocrinology 1993132 2279.e2286-2286.e2286. (https://doi.org/10.1210/endo.132.6.8504731)

2 Diamanti-Kandarakis E, Bourguignon JP, Giudice LC, Hauser R, Prins GS, Soto AM, Zoeller RT \& Gore AC. Endocrine-disrupting chemicals: an Endocrine Society scientific statement. Endocrine Reviews 200930 293-342. (https://doi.org/10.1210/er.2009-0002)

3 Vom Saal FS \& Welshons WV. Evidence that bisphenol A (BPA) can be accurately measured without contamination in human serum and urine, and that BPA causes numerous hazards from multiple routes of exposure. Molecular and Cellular Endocrinology 2014398 101-113. (https://doi.org/10.1016/j.mce.2014.09.028)

4 Richter CA, Taylor JA, Ruhlen RL, Welshons WV \& Vom Saal FS. Estradiol and bisphenol-A stimulate androgen receptor and estrogen receptor gene expression in fetal mouse prostate mesenchyme cells. Environmental Health Perspectives 2007115 902-908. (https://doi. org/10.1289/ehp.9804)

5 Nagel SC, Hagelbarger JL \& McDonnell DP. Development of an ER action indicator mouse for the study of estrogens, selective ER modulators (SERMs), and Xenobiotics. Endocrinology 2001142 4721-4728. (https://doi.org/10.1210/endo.142.11.8471)

6 Adewale HB, Jefferson WN, Newbold RR \& Patisaul HB. Neonatal bisphenol-A exposure alters rat reproductive development and ovarian morphology without impairing activation of gonadotropinreleasing hormone neurons. Biology of Reproduction 200981 690-699. (https://doi.org/10.1095/biolreprod.109.078261)

7 Geens T, Dirtu AC, Dirinck E, Malarvannan G, Van Gaal L, Jorens PG \& Covaci A. Daily intake of bisphenol A and triclosan and their association with anthropometric data, thyroid hormones and weight loss in overweight and obese individuals. Environment International 201576 98-105. (https://doi.org/10.1016/j.envint.2014.12.003)

8 Sriphrapradang C, Chailurkit LO, Aekplakorn W \& Ongphiphadhanakul B. Association between bisphenol A and abnormal free thyroxine level in men. Endocrine 201344 441-447. (https://doi.org/10.1007/s12020-013-9889-y)

9 Chitra KC, Latchoumycandane C \& Mathur PP. Induction of oxidative stress by bisphenol-A in the epididymal sperm of rats. Toxicology 2003185 119-127. (https://doi.org/10.1016/S0300483X(02)00597-8)

10 Kovacic P. How safe is bisphenol-A? Fundamentals of toxicity: metabolism, electron transfer and oxidative stress. Medical Hypotheses 201075 1-4. (https://doi.org/10.1016/j.mehy.2010.03.002)

11 Smanik PA, Liu Q, Furminger TL, Ryu K, Xing S, Mazzaferri EL $\&$ Jhiang SM. Cloning of the human sodium lodide symporter. Biochemical and Biophysical Research Communications 1996226 339-345. (https://doi.org/10.1006/bbrc.1996.1358)

12 Carvalho DP \& Ferreira AC. The importance of sodium/iodide symporter (NIS) for thyroid cancer management. Arquivos Brasileiros de Endocrinologia e Metabologia 200751 672-682. (https://doi. org/10.1590/S0004-27302007000500004)

13 Ravera S, Reyna-Neyra A, Ferrandino G, Amzel LM \& Carrasco N. The sodium/iodide symporter (NIS): molecular physiology and preclinical and clinical applications. Annual Review of Physiology 201779 261-289. (https://doi.org/10.1146/annurev-physiol-022516-034125)

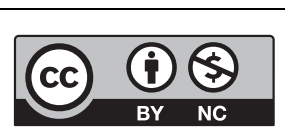

This work is licensed under a Creative Commons Attribution-NonCommercial 4.0 International License. 
14 Dupuy C, Ohayon R, Valent A, Noël-Hudson MS, Dème D \& Virion A. Purification of a novel flavoprotein involved in the thyroid NADPH oxidase. Cloning of the porcine and human cdnas. Journal of Biological Chemistry 1999274 37265-37269. (https://doi. org/10.1074/jbc.274.52.37265)

15 Figueiredo MD, Cardoso LC, Ferreira AC, Campos DV, da Cruz Domingos M, Corbo R, Nasciutti LE, Vaisman M \& Carvalho DP. Goiter and hypothyroidism in two siblings due to impaired $\mathrm{Ca}(+2) /$ $\mathrm{NAD}(\mathrm{P}) \mathrm{H}$-dependent $\mathrm{H}(2) \mathrm{O}(2)$-generating activity. Journal of Clinical Endocrinology and Metabolism 200186 4843-4848. (https://doi. org/10.1210/jcem.86.10.7934)

16 Moreno JC, Bikker H, Kempers MJ, van Trotsenburg AS, Baas F, de Vijlder JJ, Vulsma T \& Ris-Stalpers C. Inactivating mutations in the gene for thyroid oxidase 2 (THOX2) and congenital hypothyroidism. New England Journal of Medicine 2002347 95-102. (https://doi. org/10.1056/NEJMoa012752)

17 De Deken X, Wang D, Dumont JE \& Miot F. Characterization of ThOX proteins as components of the thyroid $\mathrm{H}(2) \mathrm{O}(2)$-generating system. Experimental Cell Research 2002273 187-196. (https://doi. org/10.1006/excr.2001.5444)

18 Santos MC, Louzada RA, Souza EC, Fortunato RS, Vasconcelos AL, Souza KL, Castro JP, Carvalho DP \& Ferreira AC. Diabetes mellitus increases reactive oxygen species production in the thyroid of male rats. Endocrinology 2013154 1361-1372. (https://doi.org/10.1210/ en.2012-1930)

19 Carvalho DP \& Dupuy C. Role of the NADPH oxidases DUOX and NOX4 in thyroid oxidative stress. European Thyroid Journal 20132 160-167. (https://doi.org/10.1159/000354745)

20 Fortunato RS, Ferreira AC, Hecht F, Dupuy C \& Carvalho DP. Sexual dimorphism and thyroid dysfunction: a matter of oxidative stress? Journal of Endocrinology 2014221 R31-R40. (https://doi.org/10.1530/ JOE-13-0588)

21 Chiovato L, Lapi P, Fiore E, Tonacchera M \& Pinchera A. Thyroid autoimmunity and female gender. Journal of Endocrinological Investigation 199316 384-391. (https://doi.org/10.1007/ BF03348863)

22 Aloisi AM, Della Seta D, Ceccarelli I \& Farabollini F. Bisphenol-A differently affects estrogen receptors-alpha in estrous-cycling and lactating female rats. Neuroscience Letters 2001310 49-52. (https:// doi.org/10.1016/S0304-3940(01)02092-4)

23 Honma T, Miyagawa M, Suda M, Wang RS, Kobayashi K \& Sekiguchi S. Effects of perinatal exposure to bisphenol A on brain neurotransmitters in female rat offspring. Industrial Health 200644 510-524. (https://doi.org/10.2486/indhealth.44.510)

24 Miao S, Gao Z, Kou Z, Xu G, Su C \& Liu N. Influence of bisphenol A on developing rat estrogen receptors and some cytokines in rats: a two-generational study. Journal of Toxicology and Environmental Health: Part A 200871 1000-1008. (https://doi. org/10.1080/15287390801907467)

25 McCaffrey KA, Jones B, Mabrey N, Weiss B, Swan SH \& Patisaul HB. Sex specific impact of perinatal bisphenol A (BPA) exposure over a range of orally administered doses on rat hypothalamic sexual differentiation. Neurotoxicology 201336 55-62. (https://doi. org/10.1016/j.neuro.2013.03.001)

26 Wang C, Niu R, Zhu Y, Han H, Luo G, Zhou B \& Wang J. Changes in memory and synaptic plasticity induced in male rats after maternal exposure to bisphenol A. Toxicology 2014322 51-60. (https://doi. $\operatorname{org} / 10.1016 /$ j.tox.2014.05.001)

27 Andrade MN, Santos-Silva AP, Rodrigues-Pereira P, Paiva-Melo FD, de Lima Junior NC, Teixeira MP, Soares P, Dias GRM, Graceli JB, de Carvalho DP, et al. The environmental contaminant tributyltin leads to abnormalities in different levels of the hypothalamus-pituitarythyroid axis in female rats. Environment and Pollution 201824 636-645. (https://doi.org/10.1016/j.envpol.2018.06.006)

28 Ferreira AC, Lima LP, Araújo RL, Müller G, Rocha RP, Rosenthal D \& Carvalho DP. Rapid regulation of thyroid sodium-iodide symporter activity by thyrotrophin and iodine. Journal of Endocrinology $2005 \mathbf{1}$ 69-76. (https://doi.org/10.1677/joe.1.05643)

29 Moura EG, Rosenthal D \& Carvalho-Guimarães DP. Thyroid peroxidase activity in human nodular goiters. Brazilian Journal of Medical and Biological Research 198922 31-39.

30 Bradford MM. A rapid and sensitive method for the quantitation of microgram quantities of protein utilizing the principle of proteindye binding. Analytical Biochemistry 197672 248-254. (https://doi. org/10.1016/0003-2697(76)90527-3)

31 Fortunato RS, Lima de Souza EC, Ameziane-el Hassani R, Boufraqech M, Weyemi U, Talbot M, Lagente-Chevallier O, de Carvalho DP, Bidart JM, Schlumberger M, et al. Functional consequences of dual oxidase-thyroperoxidase interaction at the plasma membrane. Journal of Clinical Endocrinology and Metabolism 201095 5403-5411. (https://doi.org/10.1210/jc.2010-1085)

32 Mühlbauer M, da Silva AC, Marassi MP, Lourenço AL, Ferreira AC \& de Carvalho DP. Retinoic acid modulation of thyroid dual oxidase activity in rats and its impact on thyroid iodine organification. Journal of Endocrinology 2010205 271-277. (https://doi.org/10.1677/ JOE-09-0421)

$33 \mathrm{Hu}$ J, Yang S, Wang Y, Goswami R, Peng C, Gao R, Zhou H, Zhang Y, Cheng Q, Zhen Q et al. Serum bisphenol A and progression of type 2 diabetic nephropathy: a 6-year prospective study. Acta Diabetologica 201552 1135-1141. (https://doi.org/10.1007/s00592-015-0801-5)

34 Hu J, Wang Y, Xiang X, Peng C, Gao R, Goswami R, Zhou H, Zhang Y, Zhen Q, Cheng Q, et al. Serum bisphenol A as a predictor of chronic kidney disease progression in primary hypertension: a 6-year prospective study. Journal of Hypertension $2016 \mathbf{3 4} 332-337$. (https:// doi.org/10.1097/HJH.0000000000000780)

35 Serrano-Nascimento C, da Silva Teixeira S, Nicola JP, Nachbar RT, Masini-Repiso AM \& Nunes MT. The acute inhibitory effect of iodide excess on sodium/iodide symporter expression and activity involves the PI3K/Akt signaling pathway. Endocrinology 2014155 1145-1156. (https://doi.org/10.1210/en.2013-1665)

36 Schmittgen TD, Lee EJ, Jiang J, Sarkar A, Yang L, Elton TS \& Chen C. Real-time PCR quantification of precursor and mature microRNA. Methods 200844 31-38. (https://doi.org/10.1016/j. ymeth.2007.09.006)

37 Bertoli S, Leone A \& Battezzati A. Human bisphenol A exposure and the 'diabesity phenotype'. Dose Response 201513 1559325815599173. (https://doi.org/10.1177/1559325815599173)

38 Ferreira AC, Neto JC, da Silva AC, Kuster RM \& Carvalho DP. Inhibition of thyroid peroxidase by Myrcia uniflora flavonoids. Chemical Research in Toxicology 200619 351-355. (https://doi. org/10.1021/tx0501684)

39 Azouzi N, Cailloux J, Cazarin JM, Knauf JA, Cracchiolo J, Al Ghuzlan A, Hartl D, Polak M, Carré A, El Mzibri M, et al. NADPH oxidase NOX4 is a critical mediator of BRAFV600E-induced downregulation of the sodium/iodide symporter in papillary thyroid carcinomas. Antioxidants and Redox Signaling 201726 864-877. (https://doi.org/10.1089/ars.2015.6616)

40 Grasberger H \& Refetoff S. Identification of the maturation factor for dual oxidase. Evolution of an eukaryotic operon equivalent. Journal of Biological Chemistry 2006281 18269-18272. (https://doi. org/10.1074/jbc.C600095200)

41 De Marco G, Agretti P, Montanelli L, Di Cosmo C, Bagattini B, De Servi M, Ferrarini E, Dimida A, Freitas Ferreira AC, Molinaro A, et al. Identification and functional analysis of novel dual oxidase 2 (DUOX2) mutations in children with congenital or subclinical hypothyroidism. Journal of Clinical Endocrinology and Metabolism 2011 96 E1335. (https://doi.org/10.1210/jc.2010-2467)

42 Corrales J, Kristofco LA, Steele WB, Yates BS, Breed CS, Williams ES $\&$ Brooks BW. Global assessment of bisphenol A in the environment: review and analysis of its occurrence and bioaccumulation. Dose Response 2015131559325815598308 . (https://doi. org/10.1177/1559325815598308)
This work is licensed under a Creative Commons Attribution-NonCommercial 4.0 International License. 
43 Choi J, Knudsen LE, Mizrak S \& Joas A. Identification of exposure to environmental chemicals in children and older adults using human biomonitoring data sorted by age: results from a literature review. International Journal of Hygiene and Environmental Health 2017220 282-298. (https://doi.org/10.1016/j.ijheh.2016.12.006)

44 Tomza-Marciniak A, Stępkowska P, Kuba J \& Pilarczyk B. Effect of bisphenol A on reproductive processes: a review of in vitro, in vivo and epidemiological studies. Journal of Applied Toxicology 201838 51-80. (https://doi.org/10.1002/jat.3480)

45 Inadera H. Neurological effects of bisphenol A and its analogues. International Journal of Medical Sciences 201512 926-936. (https://doi. org/10.7150/ijms.13267)

46 Andra SS \& Makris KC. Thyroid disrupting chemicals in plastic additives and thyroid health. Journal of Environmental Science and Health, Part C: Environmental Carcinogenesis and Ecotoxicology Reviews 201230 107-151. (https://doi.org/10.1080/10590501.2012.681487)

47 Taurog A. Hormone synthesis: thyroid iodine metabolism. In The Thyroid: A Fundamental and Clinical Text, 8th ed., pp 61-85. Eds LE Braverman \& RD Utiger. Philadelphia: Lippincott Williams \& Wilkins, 2000.

48 Dupuy C, Dème D, Kaniewski J, Pommier J \& Virion A. Ca2+ regulation of thyroid NADPH-dependent $\mathrm{H} 2 \mathrm{O} 2$ generation. FEBS Letters 1988233 74-78. (https://doi.org/10.1016/00145793(88)81358-9)

49 Song Y, Ruf J, Lothaire P, Dequanter D, Andry G, Willemse E, Dumont JE, Van Sande J \& De Deken X. Association of duoxes with thyroid peroxidase and its regulation in thyrocytes. Journal of Clinical Endocrinology and Metabolism 201095 375-382. (https://doi. org/10.1210/jc.2009-1727)

50 Ginabreda MG, Cardoso LC, Nobrega FM, Ferreira AC, Gonçalves MD, Vaisman M \& Carvalho DP. Negative correlation between thyroperoxidase and dual oxidase $\mathrm{H} 2 \mathrm{O} 2$-generating activities in thyroid nodular lesions. European Journal of Endocrinology 2008158 223-227. (doi:10.1530/EJE-07-0602)

51 Chan WK \& Chan KM. Disruption of the hypothalamic-pituitarythyroid axis in zebrafish embryo-larvae following waterborne exposure to BDE-47, TBBPA and BPA. Aquatic Toxicology 2012108 106-111. (https://doi.org/10.1016/j.aquatox.2011.10.013)

$52 \mathrm{Wu}$ Y, Beland FA \& Fang JL. Effect of triclosan, triclocarban, $2,2^{\prime}, 4,4^{\prime}$-tetrabromodiphenyl ether, and bisphenol A on the iodide uptake, thyroid peroxidase activity, and expression of genes involved in thyroid hormone synthesis. Toxicology in Vitro 201632 310-319. (https://doi.org/10.1016/j.tiv.2016.01.014)

53 Kaur S, Saluja M \& Bansal MP. Bisphenol A induced oxidative stress and apoptosis in mice testes: modulation by selenium. Andrologia 201750 e12834. (https://doi.org/10.1111/and.12834)

54 Elswefy SE, Abdallah FR, Atteia HH, Wahba AS \& Hasan RA. Inflammation, oxidative stress and apoptosis cascade implications in bisphenol A-induced liver fibrosis in male rats. International Journal of Experimental Pathology 201697 369-379. (https://doi.org/10.1111/ iep.12207)

55 Aboul Ezz HS, Khadrawy YA \& Mourad IM. The effect of bisphenol A on some oxidative stress parameters and acetylcholinesterase activity in the heart of male albino rats. Cytotechnology 201567 145-155. (https://doi.org/10.1007/s10616-013-9672-1)

56 Maier J, van Steeg H, van Oostrom C, Karger S, Paschke R \& Krohn K. Deoxyribonucleic acid damage and spontaneous mutagenesis in the thyroid gland of rats and mice. Endocrinology 2006147 3391-3397. (https://doi.org/10.1210/en.2005-1669)

57 Leoni SG, Kimura ET, Santisteban P \& De la Vieja A. Regulation of thyroid oxidative state by thioredoxin reductase has a crucial role in thyroid responses to iodide excess. Molecular Endocrinology 201125 1924-1935. (https://doi.org/10.1210/me.2011-0038)

58 Serrano-Nascimento C, Nicola JP, da Teixeira S, Poyares LL, LellisSantos C, Bordin S, Masini-Repiso AM \& Nunes MT. Excess iodide downregulates $\mathrm{Na}(+) / \mathrm{I}(-)$ symporter gene transcription through activation of PI3K/Akt pathway. Molecular and Cellular Endocrinology 2016426 73-90. (https://doi.org/10.1016/j.mce.2016.02.006)

59 Matos LPL, Cortez-Cardoso R, Cardoso-Weide LC, Freitas ML, Silva DLSG \& Ferreira ACF. Regulation of thyroid sodium-iodide symporter in different stages of goiter: possible involvement of ROS. Clinical and Experimental Pharmacology and Physiology 201845 326-334.

60 Ben-Jonathan N \& Steinmetz R. Xenoestrogens: the emerging story of bisphenol A. Trends in Endocrinology and Metabolism 19989 124-128. (https://doi.org/10.1016/S1043-2760(98)00029-0)

61 Furlanetto TW, Nguyen LQ \& Jameson JL. Estradiol increases proliferation and down-regulates the sodium/iodide symporter gene in FRTL-5 cells. Endocrinology 1999140 5705-5711. (https://doi. org/10.1210/endo.140.12.7197)

62 Kizys MML, Louzada RA, Mitne-Neto M, Jara JR, Furuzawa GK, de Carvalho DP, Dias-da-Silva MR, Nesi-França S, Dupuy C \& Maciel RMB. DUOX2 mutations are associated with congenital hypothyroidism with ectopic thyroid gland. Journal of Clinical Endocrinology and Metabolism 2017102 4060-4071. (https://doi. org/10.1210/jc.2017-00832)

63 Rigutto S, Hoste C, Dumont JE, Corvilain B, Miot F \& De Deken X. Duox1 is the main source of hydrogen peroxide in the rat thyroid cell line PCCl3. Experimental Cell Research 2007313 3892-3901. (https://doi.org/10.1016/j.yexcr.2007.06.011)

64 Rigutto S, Hoste C, Grasberger H, Milenkovic M, Communi D, Dumont JE, Corvilain B, Miot F \& De Deken X. Activation of dual oxidases Duox1 and Duox2: differential regulation mediated by camp-dependent protein kinase and protein kinase C-dependent phosphorylation. Journal of Biological Chemistry $20092846725-6734$. (https://doi.org/10.1074/jbc.M806893200)

65 Viñas R, Jeng YJ \& Watson CS. Non-genomic effects of xenoestrogen mixtures. International Journal of Environmental Research and Public Health 20129 2694-2714. (https://doi. org/10.3390/ijerph9082694)

66 Fortunato RS, Braga WM, Ortenzi VH, Rodrigues DC, Andrade BM, Miranda-Alves L, Rondinelli E, Dupuy C, Ferreira AC \& Carvalho DP. Sexual dimorphism of thyroid reactive oxygen species production due to higher NADPH oxidase 4 expression in female thyroid glands. Thyroid 201323 111-119. (https://doi.org/10.1089/ thy.2012.0142)

67 Wang C, Qi S, Liu C, Yang A, Fu W, Quan C, Duan P, Yu T \& Yang K. Mitochondrial dysfunction and $\mathrm{Ca}^{2+}$ overload in injured Sertoli cells exposed to bisphenol A. Environmental Toxicology 201732 823-831. (https://doi.org/10.1002/tox.22282)

68 Jain S, Kumar CH, Suranagi UD \& Mediratta PK. Protective effect of N-acetylcysteine on bisphenol A-induced cognitive dysfunction and oxidative stress in rats. Food and Chemical Toxicology 201149 1404-1409. (https://doi.org/10.1016/j.fct.2011.03.032)

Received in final form 19 September 2018

Accepted 25 September 2018

Accepted Preprint published online 25 September 2018 https://ec.bioscientifica.com

https://doi.org/10.1530/EC-18-0348 (c) 2018 The authors

Published by Bioscientifica Ltd

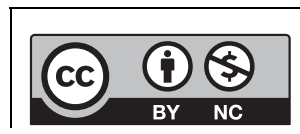

This work is licensed under a Creative Commons Attribution-NonCommercial 4.0 International License. 